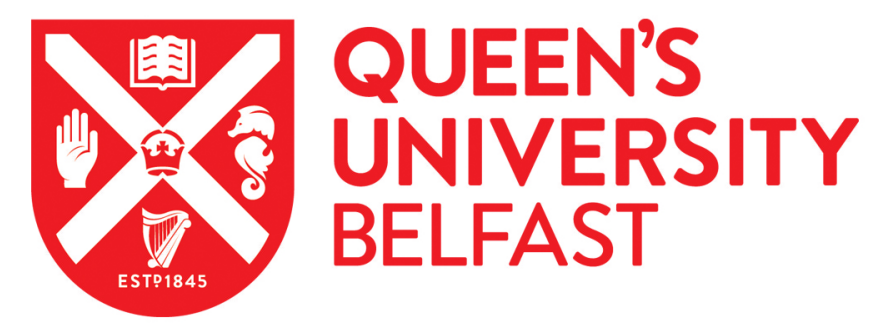

\title{
Characterisation of Robust Combustion Catalyst from Aluminium Foil Waste
}

Osman , A. I., Abu-Dahrieh, J. K., McLaren, M., Laffir, F., \& Rooney, D. W. (2018). Characterisation of Robust Combustion Catalyst from Aluminium Foil Waste. ChemistrySelect. https://doi.org/10.1002/slct.201702660

\author{
Published in: \\ ChemistrySelect
}

Document Version:

Peer reviewed version

Queen's University Belfast - Research Portal:

Link to publication record in Queen's University Belfast Research Portal

Publisher rights

Copyright 2018 Wiley.

This work is made available online in accordance with the publisher's policies. Please refer to any applicable terms of use of the publisher.

\section{General rights}

Copyright for the publications made accessible via the Queen's University Belfast Research Portal is retained by the author(s) and / or other copyright owners and it is a condition of accessing these publications that users recognise and abide by the legal requirements associated with these rights.

Take down policy

The Research Portal is Queen's institutional repository that provides access to Queen's research output. Every effort has been made to ensure that content in the Research Portal does not infringe any person's rights, or applicable UK laws. If you discover content in the Research Portal that you believe breaches copyright or violates any law, please contact openaccess@qub.ac.uk. 


\section{Characterisation of Robust Combustion Catalyst from}

\section{Aluminium Foil Waste}

Ahmed I. Osmana, ${ }^{a, b *}$ Jehad K. Abu-Dahrieha, Mathew McLarenc, Fathima Laffird, David

$$
\text { W.Rooney }{ }^{a}
$$

a School of Chemistry and Chemical Engineering, Queen's University, David Keir Building, Stranmillis Road, Belfast BT9 5AG, Northern Ireland, United Kingdom

${ }^{b}$ Chemistry Department, Faculty of Science - Qena, South Valley University, Qena 83523 Egypt.

'Centre for Nanostructured Media, School of Mathematics and Physics, Queen's University Belfast, BT7 1NN, UK.

${ }^{d}$ Department of Chemical and Environmental Sciences, Materials and Surface Science Institute, University of Limerick, Limerick, Ireland

${ }^{*}$ Corresponding authors Dr. Ahmed I. Osman, Dr. Jehad K. Abu-Dahrieh

E-mail: aosmanahmed01@qub.ac.uk, j.abudahrieh@qub.ac.uk

Address: School of Chemistry and Chemical Engineering, Queen's University Belfast, David Keir Building, Stranmillis Road, Belfast BT9 5AG, Northern Ireland, United Kingdom

Fax: +44 2890974687

Tel.: +442890974412 


\section{Abstract}

Herein a robust and active combustion catalyst was prepared with three-quarter (75 wt.\%) of its composition derived from the aluminium foil waste and designated as 5PdACFL. The prepared catalyst was characterised using X-ray diffraction (XRD), Temperature-programmed reduction (TPR), Bright-field transmission electron microscopy (BF-TEM), High angle annular dark field (HAADF), Fourier transform infrared-pyridine (FTIR-Pyridine) and X-ray Photoelectron Spectroscopy (XPS) techniques and compared to the commercial equivalent (5Pd-AC550). The catalyst 5Pd-ACFL550 showed higher catalytic activity than that of 5Pd-AC550 in the total methane oxidation reaction with $\mathrm{T}_{50 \%}$ at $303^{\circ} \mathrm{C}$ at Gas hourly space velocity (GHSV) of $100,000 \mathrm{~mL} \mathrm{~g}^{-1} \mathrm{~h}^{-1}$. Our approach opens doors for the preparation of robust cheap combustion catalyst from aluminium foil waste and demonstrates its application in the catalytic converters of natural gas vehicles (NGV-vehicles) and other combustion applications. As a result, this can be opened up to a wider variety of application markets, including residential and automotive applications. 


\section{Introduction}

Aluminium oxide, alumina $\left(\mathrm{Al}_{2} \mathrm{O}_{3}\right)$, is one of the most attractive ceramic materials for its various applications due to its thermal, chemical and mechanical stability. ${ }^{[1]}$ For example, it is used as a catalyst support, adsorbent, ion exchangers, abrasives, in electronic device fabrication, filter, as a cutting tool material, or as an alternative for surgical material for implants. ${ }^{[2]} \mathrm{Al}_{2} \mathrm{O}_{3}$ exists in a range of metastable structures, the so-called transition aluminas, e.g. $x, k, \gamma, \delta, \eta, \Theta$ as well as its stable $\alpha-\mathrm{Al}_{2} \mathrm{O}_{3}$ corundum phase. This polymorphism can be classified in terms of the oxygen sublattice structure (OSS) and the distribution of $\mathrm{Al}^{3+}$ in tetrahedral and octahedral interstitial sites. ${ }^{[1 \mathrm{a}]}$ Thus, in $\alpha-\mathrm{Al}_{2} \mathrm{O}_{3}$ (trigonal), the OSS is hexagonal close-packed (hcp) structured with $2 / 3$ of the octahedral sites occupied by cations, while $\gamma, \delta$ (either tetragonal or orthorhombic), $\eta$ (cubic), $\Theta$ (monoclinic) have a face-centered cubic (fcc) arrangement of oxygen anions and $\mathrm{Al}$ cations present in various proportions in both octahedral and tetrahedral sites. It has been established that boehmite transforms into stable $\alpha-\mathrm{Al}_{2} \mathrm{O}_{3}$ via the following sequence. ${ }^{[1 \mathrm{a}]}$

$$
\mathrm{AlO}(\mathrm{OH}) \rightarrow \mathrm{\gamma} \rightarrow \delta \rightarrow \Theta \rightarrow \alpha-\mathrm{Al}_{2} \mathrm{O}_{3}
$$

$\mathrm{Al}_{2} \mathrm{O}_{3}$ can be prepared in different phases, for instance, the dehydration of boehmite at $300-500{ }^{\circ} \mathrm{C}$ yields $\mathrm{y}-\mathrm{Al}_{2} \mathrm{O}_{3}$, while in a temperature range of $700-800{ }^{\circ} \mathrm{C}$ it produces $\delta$ $\mathrm{Al}_{2} \mathrm{O}_{3}$, at a higher temperature range of $900-1000{ }^{\circ} \mathrm{C}$ it gives $\theta-\mathrm{Al}_{2} \mathrm{O}_{3}$, and at 1000 $1200{ }^{\circ} \mathrm{C}, \alpha-\mathrm{Al}_{2} \mathrm{O}_{3}$ is produced. ${ }^{[2]}$ Among the various crystalline phases of alumina, $\mathrm{y}^{-}$ $\mathrm{Al}_{2} \mathrm{O}_{3}$ has received much attention due to a reduced generation of by-products. ${ }^{[3]}$ Nonporous crystalline $\mathrm{Y}-\mathrm{Al}_{2} \mathrm{O}_{3}$ has been widely used as a support in catalytic processes, such as polymerization, reforming, oxy-reforming, dehydration, hydrogenation and in the synthesis of biodiesel. ${ }^{[4]}$ It offers good surface characteristics in heterogeneous catalysis, such as large specific surface area, pore size, pore 
volume and a highly active site concentration on its surface. Usually, Alumina support is produced from bauxite ore, which is mined in countries such as West Africa, the West Indies and Australia. It causes massive environmental damage by generating considerable levels of waste such as tailings, red mud, emissions of perfluorocarbon and $\mathrm{CO}_{2}$ gases during the production process.

In a previous work, a novel, eco-friendly synthesis of mesoporous alumina catalyst ( $\gamma$ $\mathrm{Al}_{2} \mathrm{O}_{3}$ ) was performed from aluminium foil waste (AFW) with surface and bulk characteristics better than commercial alumina in term of the surface structure (morphology, surface area and pore volume) along with the surface acidity. ${ }^{[5]}$ Our approach could decrease the quantity of AFW whereas avoids the environmental damage related with mining bauxite, the primary ore of aluminium, that's necessary to meet ever increasing the global aluminium consumption. In order to prepare $1 \mathrm{Kg}$ of alumina catalyst, $\sim 530 \mathrm{gm}$ of the $\mathrm{AFW}$ is needed along with about $9 \mathrm{~L}$ of $\mathrm{HCl}(30 \% \mathrm{w} / \mathrm{w})$ and 9L of ammonia solution (30\% solution) with a total cost of $£ 120$ per $\mathrm{Kg}$ of the alumina catalyst. The average cost of the commercial alumina catalyst is about $£ 305$ per $\mathrm{Kg}$, so this novel idea can make a highly active catalyst with less than half the cost of the commercial alumina catalyst. However, in commercial alumina production, besides raw material cost, there is also labour cost, equipment cost, etc, which should be also considered.

One of the applications of the modified $\mathrm{y}-\mathrm{Al}_{2} \mathrm{O}_{3}$ is in the total methane oxidation (TMO) as a catalyst support. Recently, the bimetallic Pd-Pt loaded on a dual component support showed superior activity in the TMO reaction of palladium being the most active component and platinum enhanced the stability of the palladium species in the catalyst composition $\left(5 \% \mathrm{Pd}+2 \% \mathrm{Pt} / 17.5 \% \mathrm{TiO}_{2} / \mathrm{ZSM}-5(80)\right){ }^{[6]}$ It is well known that the acidic support is crucial for the TMO reaction as it makes the Pd metal more electron 
deficient and enhances the re-oxidation of $\mathrm{Pd}(0)$ during $\mathrm{Pd}(0) / \mathrm{PdO}$ redox cycle, consequently improving the catalytic activity. ${ }^{[6-7]}$ The role for the oxygen storage $\left(\mathrm{TiO}_{2}\right)$ is to improve the oxygen mobility along with facilitating the reduction of the Pd species during the redox cycle in the TMO reaction and consequently improve the catalytic performance. Lin et al. ${ }^{[7]}$ reported a decrease of $\mathrm{T}_{10 \%}$ by $30{ }^{\circ} \mathrm{C}$ on the addition of titania in the catalyst composition of $\left(\mathrm{Pd} / \mathrm{TiO}_{2} / \mathrm{Al}_{2} \mathrm{O}_{3}\right)$, where $\mathrm{T}_{10} \%>250{ }^{\circ} \mathrm{C}, \mathrm{GHSV}=33,000 \mathrm{~mL}$ $\mathrm{h}^{-1} \mathrm{~g}^{-1}$. Miller et al. ${ }^{[8]}$ studied the effect of the support on the palladium species for the TMO reaction and found that the activity results showed the following sequence $\mathrm{Pd} / \mathrm{Al}_{2} \mathrm{O}_{3}>\mathrm{Pd} / \mathrm{Ce}-\mathrm{Zr}>\mathrm{Pd} / \mathrm{Ce}$.

The above discussion leads to the conclusion that converting AFW into mesoporous $\mathrm{Y}^{-}$ $\mathrm{Al}_{2} \mathrm{O}_{3}$ (catalyst/support) using a cost-effective green synthetic route is highly desirable. Recently, we demonstrated a novel, eco-friendly synthesis of mesoporous $\mathrm{Y}-\mathrm{Al}_{2} \mathrm{O}_{3}$ from AFW (ACFL550) with surface and bulk characteristics better than commercial $y^{-}$ $\mathrm{Al}_{2} \mathrm{O}_{3}$ (AC550). Herein, we propose a robust combustion catalyst derived from the bimetallic $\mathrm{Pd}-\mathrm{Pt}$ metals loaded on $\mathrm{y}-\mathrm{Al}_{2} \mathrm{O}_{3}$ that produced from $\mathrm{AFW}$.

The preparation and characterisation techniques are shown in the supplementary.

\section{Results and Discussion}

\subsection{Characterisation of pure catalysts derived from the ultrapure single crystals}

The crystallite size calculated by the Scherrer equation showed that pure ACFL550 and AC550 have relatively similar crystallite sizes as shown in Table 1. The adsorption/desorption isotherm of pure ACFL550 is shown in Figure S1, demonstrating it is a type IV isotherm which is typically attributed to the mesoporous structure. X-ray single crystal of a trigonal crystal system with a space group of R-3c of homemade aluminium chloride hexahydrate derived from AFW is shown in Figure 1. 


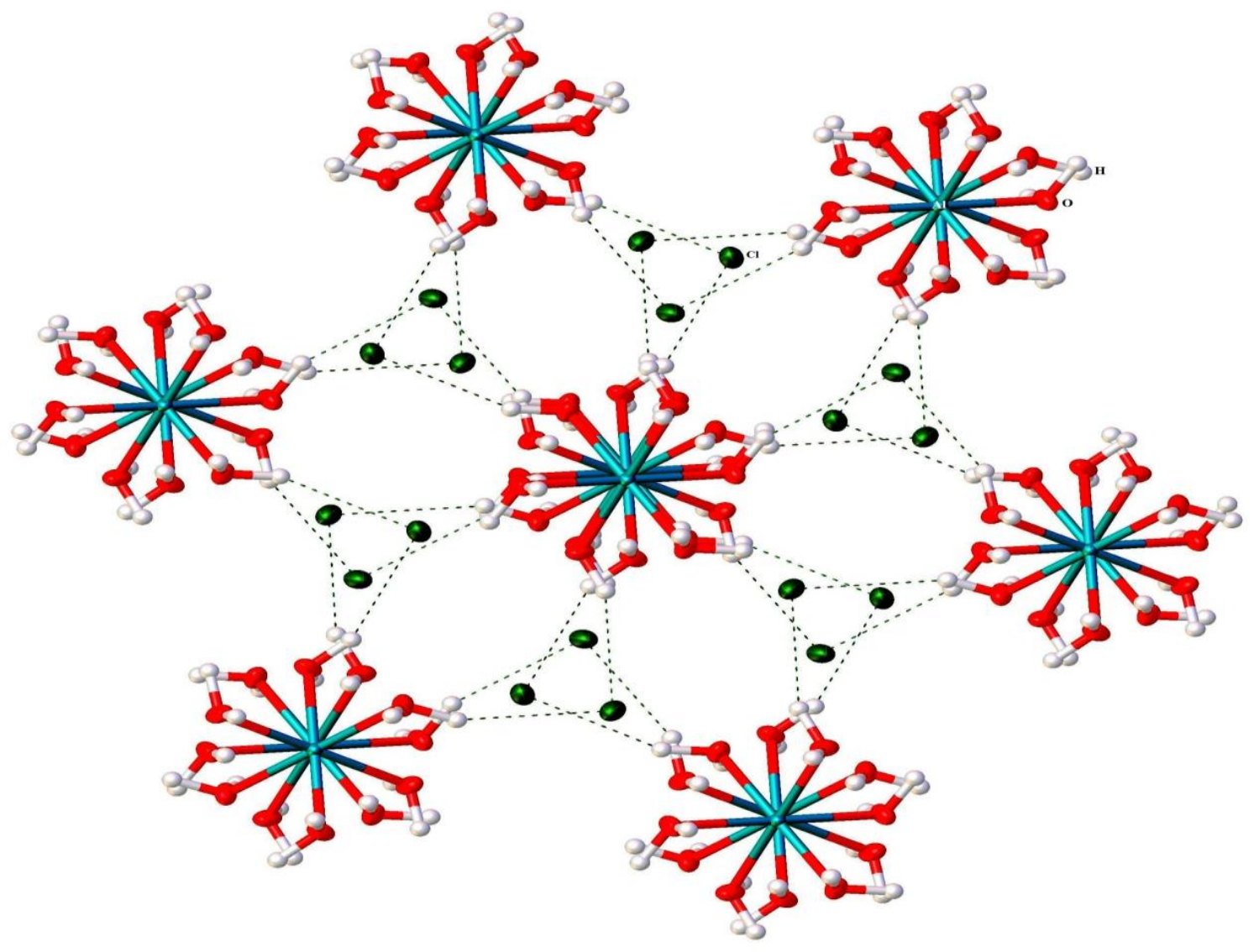

Figure 1: X-ray single crystal of homemade aluminium chloride hexahydrate depict the packing cubic crystal structure viewed along [001]. 
Table 1: shows the surface area $\left(S_{B E T}\left(\mathrm{~m}^{2} \mathrm{~g}^{-1}\right)\right)$, acidity and pore volume $\left(\mathrm{cm}^{3} \mathrm{~g}^{-1}\right)$ for different acidic supports and their catalyst prepared.

\begin{tabular}{|c|c|c|c|c|c|}
\hline $\begin{array}{c}\text { Support / } \\
\text { Catalyst }\end{array}$ & $\mathrm{S}_{\mathrm{BET}}\left(\mathrm{m}^{2} \mathrm{~g}^{-1}\right)$ & $\begin{array}{c}\text { Crystallite } \\
\text { size } \\
(\mathrm{nm})\end{array}$ & $\begin{array}{c}\text { Pore volume } \\
\left(\mathrm{cm}^{3} \mathrm{~g}^{-1}\right)\end{array}$ & $\begin{array}{c}\text { Total acidity } \\
\mathrm{A}(\mathrm{sites} / \mathrm{g})\end{array}$ & $\begin{array}{c}\text { Acid density } \\
\mathrm{b}, \\
\mathrm{B}\left(\mathrm{sites} / \mathrm{m}^{2}\right)\end{array}$ \\
\hline ACFL120 & 387 & 3.0 & 0.36 & - & - \\
\hline AC120 & 378 & 3.1 & 0.20 & - & - \\
\hline ACFL550 & 300 & 3.5 & 0.45 & 7.01 & 2.4 \\
\hline AC550 & 278 & 3.7 & 0.35 & 6.91 & -- \\
\hline 5 Pd-ACFL550 & 254 & 13 & 0.32 & -- & - \\
\hline 5Pd-AC550 & 233 & 15 & 0.22 & -- & - \\
\hline 93\% TiO 2 & 107 & 51 & 0.27 & - & - \\
\hline
\end{tabular}

a Total acidity $=\mathrm{A} \times 10^{20}$.

${ }^{\mathrm{b}}$ Acid density $=\mathrm{B} \times 10^{18}$

\subsection{Characterisation of $5 \mathrm{Pd}-\mathrm{ACFL} 550$ and $5 \mathrm{Pd}-\mathrm{AC} 550$ used for the TMO} reaction

The SBET and the pore volume of the modified catalysts (5Pd-ACFL550, 5Pd-AC550 and $93 \% \mathrm{TiO}_{2}$ catalysts) are shown in Table 1, which reflect the surface area of the supports that were used during the preparation where 5Pd-ACFL550 catalyst has the highest surface area whereas $93 \% \mathrm{TiO}_{2}$ catalyst showed the lowest surface area. The XRD of these modified catalysts along with the supports is shown in Figure 2. The diffraction lines of $\mathrm{TiO}_{2}$ that correspond to the anatase phase (JCPDS 21-1272) appeared in all the prepared catalysts. The diffraction peak at $2 \theta=33.8$ is attributed to the PdO phase ${ }^{[6]}$ with a larger peak in $5 \mathrm{Pd}-\mathrm{ACF} 550$ catalyst than that of $5 \mathrm{Pd}-\mathrm{AC} 550$ catalyst and the $93 \% \mathrm{TiO}_{2}$ catalyst, where the peak is less visible, implying the formation of palladium oxide species on the surface of the 5Pd-ACFL550 catalyst was the highest among the modified catalysts. 


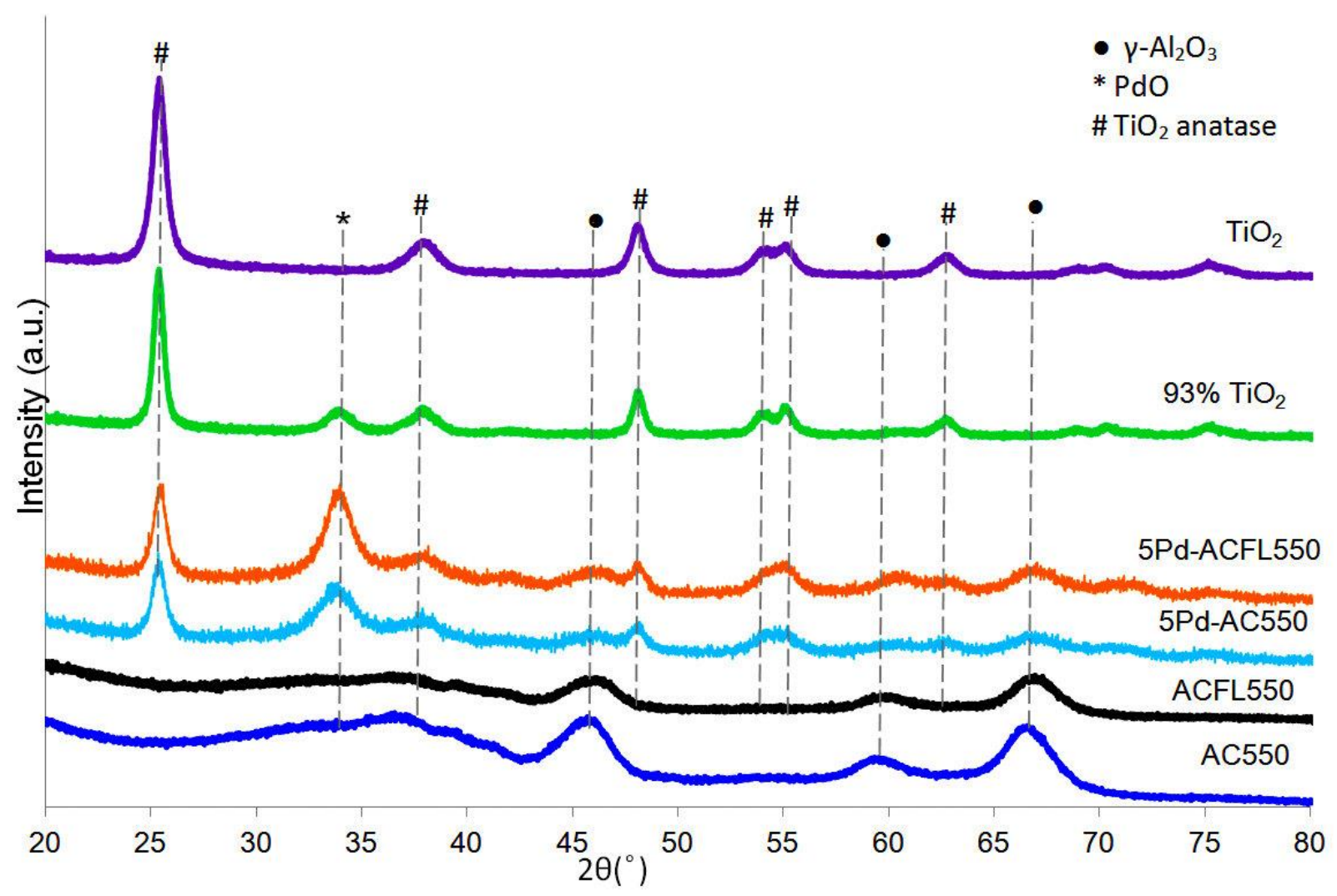

Figure 2: XRD patterns of the modified catalysts, $5 P d-A C 550,5 P d-A C F L 550$ and $93 \%$ $\mathrm{TiO}_{2}$ catalysts along with the supports used during the preparation (AC550 (commercial aluminium chloride), ACFL550 (AFW) and $\mathrm{TiO}_{2}$ supports).

The surface oxides of the modified catalysts were investigated using XPS analysis. Survey spectra of all three catalysts; 5Pd-ACFL550, 5Pd-AC550 and 93\% $\mathrm{TiO}_{2}$ showed the presence of both Pt and Pd (Figure S2 (a)). Figures 3 and S2 (b) show high-resolution spectra of $\mathrm{Pd} 3 d, \mathrm{Pt} 4 f, \mathrm{O} 1 \mathrm{~s}$ and $\mathrm{Ti} 2 \mathrm{p}$, The palladium species predominantly exist as $\mathrm{PdO}$ with binding energies of approximately $336.6 \mathrm{eV}\left(\mathrm{Pd} 3 d_{5 / 2}\right)$ and $342.3 \mathrm{eV}\left(\mathrm{Pd}_{3} d_{3 / 2}\right)$ along with a small contribution of $\mathrm{PdO}_{2}$ at higher binding energy, ${ }^{\left[{ }^{[9]}\right.}$ as seen in Figure 3 (a). Platinum $4 f$ region overlaps with $\mathrm{Al} 2 p$ as shown in Figure 3(b) for samples with $\mathrm{Al}_{2} \mathrm{O}_{3}$. However, these can be compared with $\mathrm{Pt}$ 4f of $93 \% \mathrm{TiO}_{2}$ catalyst which has no aluminium and it is seen that $\mathrm{Pt} 4 f_{7 / 2}$ peak for all three catalysts appear at $71.8 \mathrm{eV}$ which can be attributed to $\mathrm{Pt}(0)$ state and a minor contribution from $\mathrm{Pt}(+2)$ at a higher energy of approximately $73 \mathrm{eV} \cdot{ }^{[10]}$ The $\mathrm{O} 1 \mathrm{~s}$ 
spectrum can be fitted with component peaks to show the existence of the related oxygens from the metal oxides $\left(\mathrm{PdO}, \mathrm{PdO}_{2}, \mathrm{TiO}_{2}\right.$ or $\left.\mathrm{Al}_{2} \mathrm{O}_{3}\right)$ and hydroxides at binding energies approximately 529-531.5 and 533.1 eV, respectively as seen in Figure 3(c). It is not surprising that $93 \% \mathrm{TiO}_{2}$ catalyst showed the largest $\mathrm{Ti} 2 p_{3 / 2}$ peak among the modified catalysts (Figure S2 (b)) and this is attributed to the higher $\mathrm{TiO}_{2}$ content in the catalyst composition (93 wt.\%) compared to $17.5 \mathrm{wt} . \%$ for the other catalysts. ${ }^{[11]}$ 

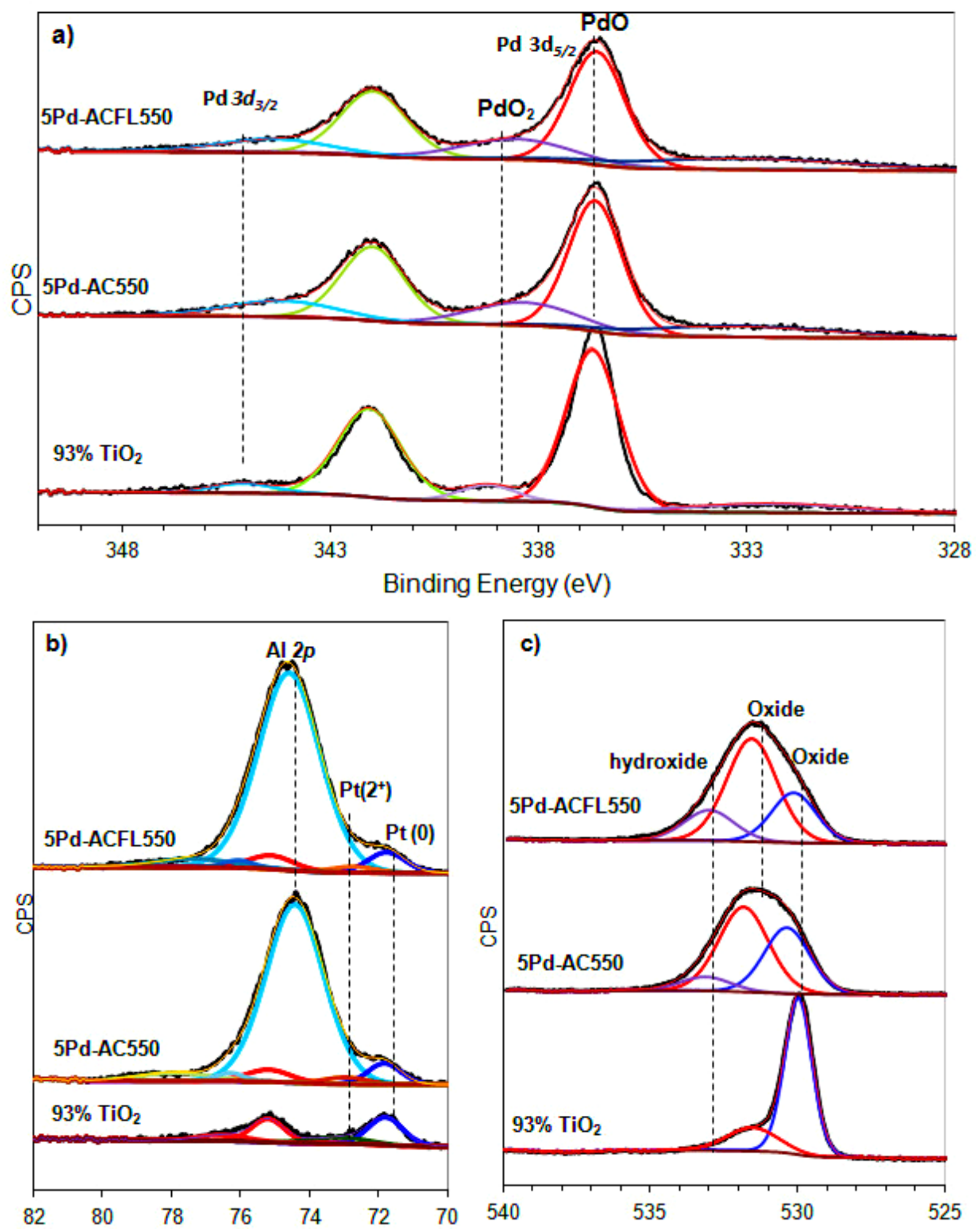

Figure 3: XPS of 5Pd-ACFL550, 5Pd-AC550 and $93 \% \mathrm{TiO}_{2}$ catalysts a) $\mathrm{Pd} 3 d$, b) Pt4f and c) $01 s$. 
The pure ACFL550 catalyst showed nano-rod particles of less than $10 \mathrm{~nm}$ in size as shown in a previous work..$^{[5]}$ TEM analysis of the $5 \mathrm{Pd}$-ACFL550 catalyst is shown in Figure 4(a-c), where image (a) and (b) show the transmission electron micrographs of the catalyst in bright field and STEM modes, respectively, wherein the HAADF the bimetallic $(\mathrm{Pd} / \mathrm{Pt})$ and $\mathrm{TiO}_{2}$ appears to be located in regions of brighter contrast. Figure 4 (c) shows elemental maps acquired by STEM-EDX of the principle elements in the 5Pd-ACFL550 catalyst. As expected, the alumina structure is dominant, with Ti found around the edges. The Pd and Pt signals are similar to each other, dispersed across the support structure with a fairly random distribution. The particle size of the palladium was around $13 \mathrm{~nm}$ as shown in Figure S3 (c). 

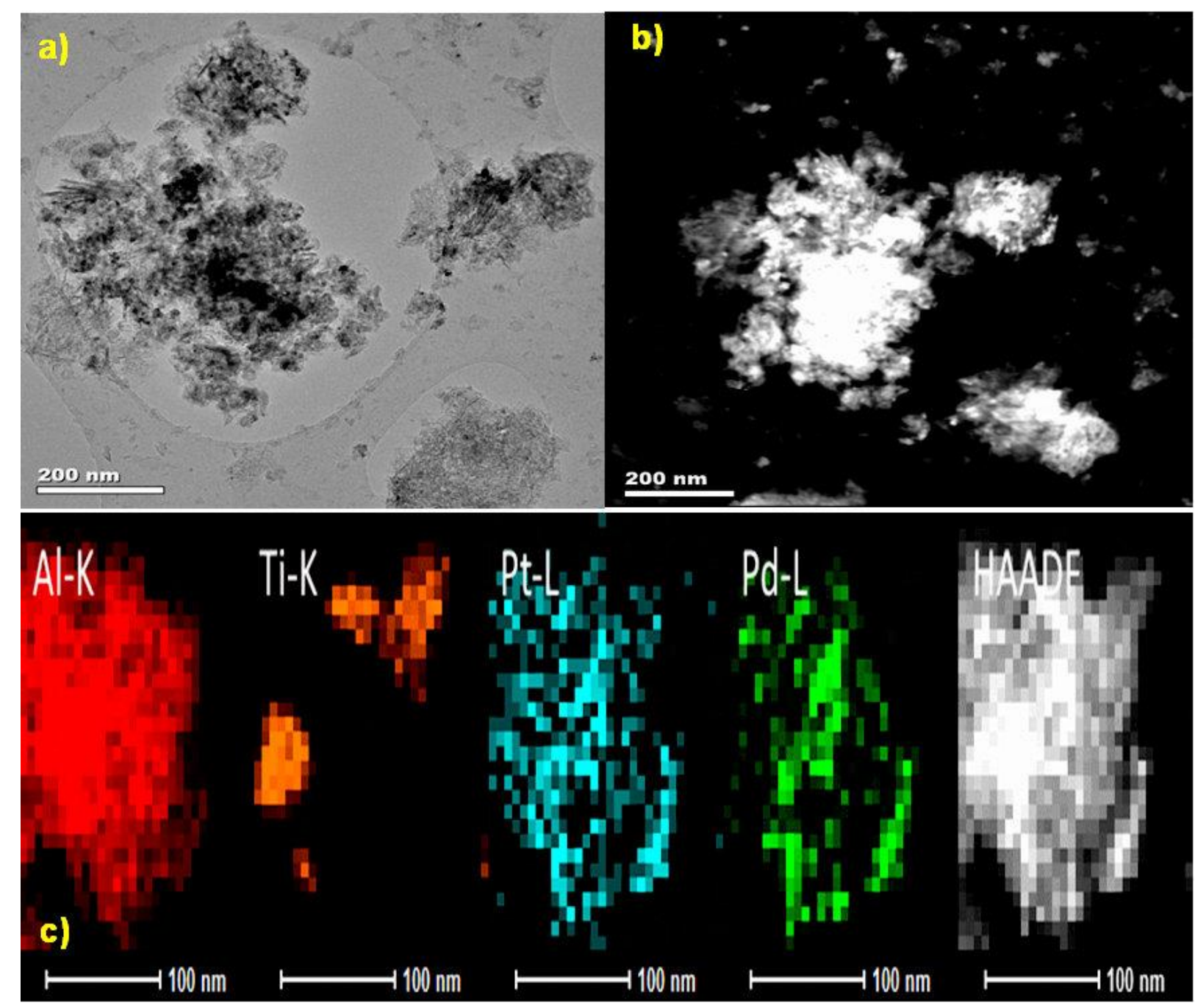

Figure 4: TEM overview image a) and b) show TEM-BF of the 5Pd-ACFL550 catalyst in bright field and STEM modes, respectively. Image c) shows the EDX spectral images taken from the 5Pd-ACFL550 catalyst of the Al-K, Ti-K, Pd-L and Pt-L peaks.

The enhanced reducibility of the catalyst is a crucial criterion during the redox cycle in the combustion reaction. ${ }^{6]}$ The $\mathrm{H}_{2}$-TPR spectra of $5 \mathrm{Pd}-\mathrm{ACFL} 550$ and $93 \% \mathrm{TiO}_{2}$ catalysts along with the supports (ACFL550 and $\mathrm{TiO}_{2}$ supports) are shown in Figure 5 and show the influence of the support on the palladium species. No reduction peak is seen for the ACFL550 support whereas the titania oxide support showed a broad reduction peak in the temperature range of $330-550 \stackrel{\circ}{ } \mathrm{C}$, which is attributed to the 
reduction of $\mathrm{Ti}^{4+}$ to $\mathrm{Ti}^{3}{ }_{,}^{[6]}$ where this peak was shifted to lower reduction temperature $\left(200-400{ }^{\circ} \mathrm{C}\right)$ in $5 \mathrm{Pd}-\mathrm{ACFL} 550$ and $93 \% \mathrm{TiO}_{2}$ catalysts. This implies that the reducibility of $\mathrm{TiO}_{2}$ was enhanced with the metals and the alumina support. Osman et al., ${ }^{[6]}$ showed that $\mathrm{TiO}_{2}$ enhanced the reducibility of the palladium species while the acidic support (alumina) increased the electrophilicity of the $\mathrm{Pd}$ species and consequently enhanced the re-oxidation of the catalyst. With high $\mathrm{TiO}_{2}$ loading as in $93 \% \mathrm{TiO}_{2}$ catalyst the palladium species are more readily reducible and as a result, a negative peak was observed around $38^{\circ} \mathrm{C}$. This is attributed to the $\beta$-hydride of the palladium metal $\mathrm{Pd}(0)$ and only appeared in that catalyst along with a positive reduction peak around $1{ }^{\circ} \mathrm{C}$ which is attributed to the $\mathrm{PdO}$ phase. Catalyst $5 \mathrm{Pd}$ ACFL550 showed two positive reduction peaks for the PdO species around 1 and 80 ${ }^{\circ} \mathrm{C}$, this is due to the catalyst composition which is mainly acidic support (75.5 wt.\%) that enhanced the re-oxidation of the palladium species over the surface of the catalyst. These results are in agreement with the XRD results where 5Pd-ACFL550 catalyst showed the highest $\mathrm{PdO}$ diffraction peak while $93 \% \mathrm{TiO}_{2}$ showed the smallest PdO diffraction peak. However, $93 \% \mathrm{TiO}_{2}$ catalyst showed facile reduction behaviour, there was a poor dispersion of the metals on the surface and led to the formation of big clusters as shown in Figure S4. The maps showed high agglomeration of $\mathrm{Ti}, \mathrm{Pd}$ and $\mathrm{O}$ and slightly less of $\mathrm{Pt}$ species on the surface of the catalyst which was confirmed by the XPS results as predominantly Pt metal phase (Figure 3(b)). 


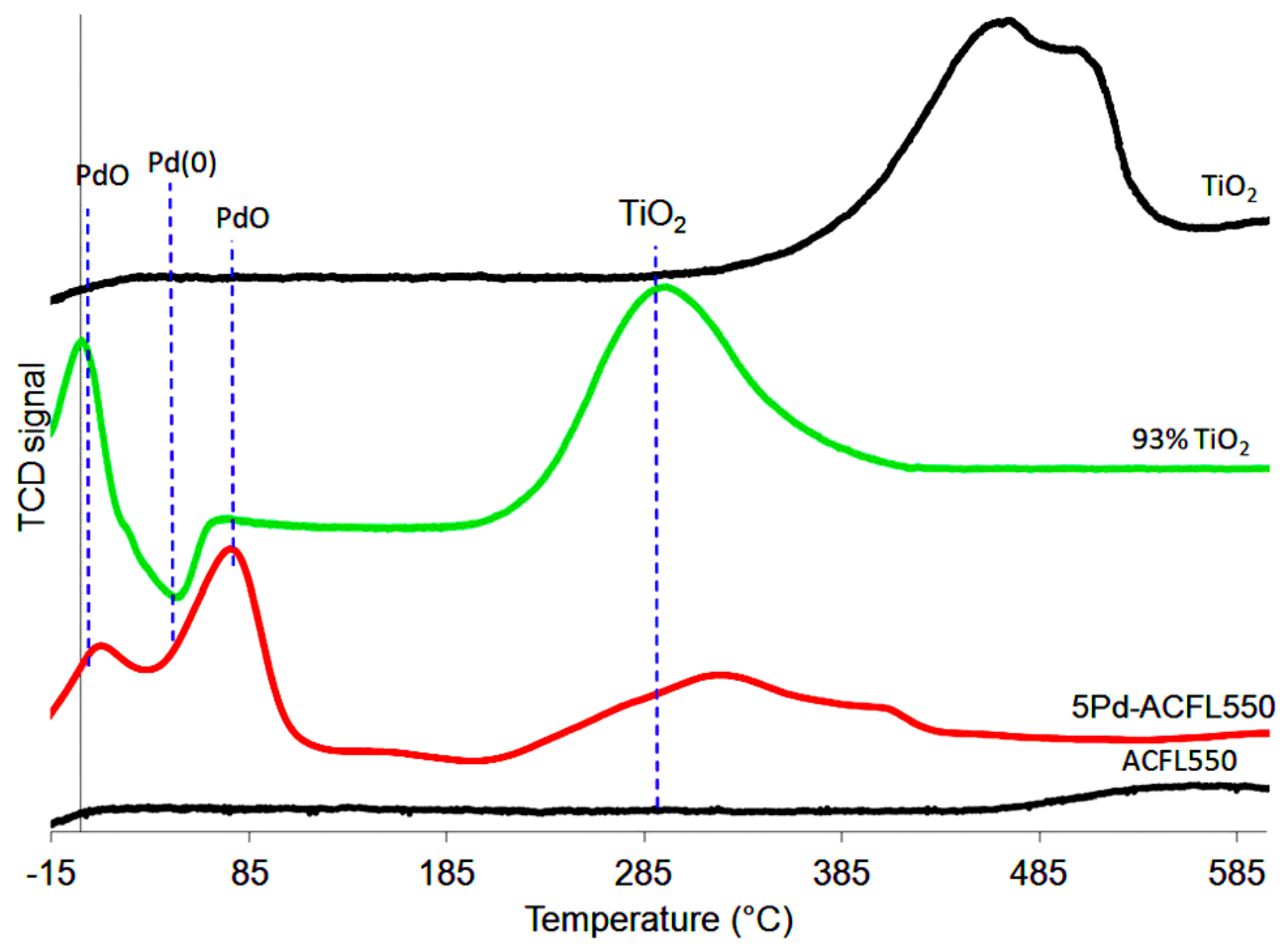

Figure 5: TPR spectra of $5 \mathrm{Pd}-\mathrm{ACFL} 550$ and $93 \% \mathrm{TiO}_{2}$ catalysts along with the supports used during the preparation (ACFL550 and $\mathrm{TiO}_{2}$ supports).

The FTIR pyridine spectra of the 5Pd-ACFL550 catalyst along with the supports of ACFL550 and $\mathrm{TiO}_{2}$ are shown in Figure S5. The surface acidity of the ACFL550 support was slightly changed upon deposition of $\mathrm{Pd}, \mathrm{Pt}$ and $\mathrm{TIO}_{2}$ with Lewis acidic sites being the dominating acidic sites on the surface of the catalyst. It is obvious that the $\mathrm{TiO}_{2}$ support showed the smallest amount of Lewis acidic peaks among these catalysts. 


\section{Catalyst applications in acid-catalysed reactions}

\subsection{The total methane oxidation reaction}

The catalytic activity tests were performed elsewhere, ${ }^{[5]}$ and it was obvious that the catalysts that have acidic support component (5Pd-ACFL550 and 5Pd-AC550) showed higher catalytic activity than that of the mono-component support, without acidic support, $\left(93 \% \mathrm{TiO}_{2}\right)$. The lower catalytic activity in the $93 \% \mathrm{TiO}_{2}$ catalyst is due to the absence of the acidic support in the catalyst composition. The catalytic activity of 5Pd-ACFL550 (derived from AFW) catalyst was apparently higher than that of 5PdAC550 (derived from the Al chloride precursor) and $93 \% \mathrm{TiO}_{2}$ catalysts with $\mathrm{T}_{50 \%}$ at 303,321 and $340{ }^{\circ} \mathrm{C}$, respectively. The superior catalytic activity of $5 \mathrm{Pd}-\mathrm{ACFL} 550$ compared to 5Pd-AC550 may be due to the stronger Lewis acidic sites in the ACFL550 than the AC550 supports as shown in the FTIR-pyridine and TPD-Pyridine as well as the higher surface area and bigger pore volume as seen in Table 1. Furthermore, the chlorine contents are known to block the active sites on the catalyst surface and consequently lead to catalytic deactivation. ${ }^{[7,12]}$ EDX analysis showed that the $\% \mathrm{Cl}$ in ACFL550 is half that of AC550 with 1.8 and 3.8, respectively (not shown). Thus, it is not surprising that $5 \mathrm{Pd}-\mathrm{ACF} 550$ showed a higher catalytic activity than that of 5Pd-AC550 in the TMO reaction. The time on stream test for the 5Pd-ACFL550 catalyst showed a good stability during the 50 hrs TOS test. 


\section{Conclusions}

Herein, we characterise a robust combustion catalyst derived from AFW with high activity in the $\mathrm{TMO}$ reaction with $\mathrm{T}_{50 \%}$ at $303^{\circ} \mathrm{C}$. Four components are needed for a highly active methane combustion catalyst. Palladium as the active metal species, platinum to stabilise the palladium, $\mathrm{TiO}_{2}$ as an oxygen carrier to ensure a good supply of oxygen and $\mathrm{y}^{-} \mathrm{Al}_{2} \mathrm{O}_{3}$ (derived from $\mathrm{AFW}$ ) as an acidic support to activate the methane and increase the electrophilicity of palladium, hence the re-oxidation during the redox cycle in the TMO reaction. All components are needed to work together to achieve optimum activity and stability. STEM-EDX of the most active catalyst $(5 \mathrm{Pd}-$ ACFL550) showed that the catalyst structure is dominated by alumina, with $\mathrm{Ti}$ found around the edges. The bimetallic Pd-Pt metals are similar to each other, dispersed across the support structure with a fairly random distribution. These results open doors for the preparation of highly active and well-structured nano-mesoporous alumina catalyst/support from AFW and its application in acid catalysed reactions and especially in combustion reactions.

\section{Supporting Information Summary}

Experimental section and catalyst characterisation techniques along with the following figures (SBET, XPS, TEM, SEM/EDX and FTIR-Pyridine spectra).

Competing financial interests: The authors declare no competing financial interests.

Acknowledgements: The authors would like to acknowledge the support given to AO from the School of Chemistry and Chemical Engineering, Queen's University Belfast along with South Valley University in Egypt. 
Keywords: aluminium foil, aluminium waste, combustion catalyst, $\mathrm{y}-\mathrm{Al}_{2} \mathrm{O}_{3}$, Palladium, total methane oxidation.

\section{References}

[1] a) A. Boumaza, L. Favaro, J. Ledion, G. Sattonnay, J. B. Brubach, P. Berthet, A. M. Huntz, P. Roy, R. Tetot, J. Solid State Chem. 2009, 182, 1171-1176; b) H. A. Dabbagh, K. Taban, M. Zamani, J. Mol. Catal. A: Chem. 2010, 326, 55-68.

[2] A. I. Osman, J. K. Abu-Dahrieh, D. W. Rooney, S. A. Halawy, M. A. Mohamed, A. Abdelkader, Appl. Catal., B 2012, 127, 307-315.

[3] J. Khom-in, P. Praserthdam, J. Panpranot, O. Mekasuwandumrong, Catal. Commun. 2008, 9, 1955-1958.

[4] a) T. Mathew, Y. Yamada, A. Ueda, H. Shioyama, T. Kobayashi, Appl. Catal., A. 2005, 286, 1122; b) A. I. Osman, J. K. Abu-Dahrieh, D. W. Rooney, J. Thompson, S. A. Halawy, M. A. Mohamed, J. Chem. Technol. Biotechnol. 2017, 92, 2952-2962; c) A. I. Osman, J. K. AbuDahrieh, A. Abdelkader, N. M. Hassan, F. Laffir, M. McLaren, D. Rooney, J. Phys. Chem. C. 2017, 121, 25018-25032; d) A. I. Osman, J. Meudal, F. Laffir, J. Thompson, D. Rooney, Appl. Catal., B 2017, 212, 68-79.

[5] A. I. Osman, J. K. Abu-Dahrieh, M. McLaren, F. Laffir, P. Nockemann, D. Rooney, Sci. Rep. 2017, 7, 3593.

[6] A. I. Osman, J. K. Abu-Dahrieh, F. Laffir, T. Curtin, J. M. Thompson, D. W. Rooney, Appl. Catal., B. 2016, 187, 408-418.

[7] W. Lin, Y. X. Zhu, N. Z. Wu, Y. C. Xie, I. Murwani, E. Kemnitz, Appl. Catal., B. 2004, 50, 59-66.

[8] J. B. Miller, M. Malatpure, Appl Catal., A. 2015, 495, 54-62.

[9] L. S. Kibis, A. I. Stadnichenko, S. V. Koscheev, V. I. Zaikovskii, A. I. Boronin, J. Phys. Chem. C. 2012, 116, 19342-19348.

[10] A. V. Grigorieva, E. A. Goodilin, L. E. Derlyukova, T. A. Anufrieva, A. B. Tarasov, Y. A. Dobrovolskii, Y. D. Tretyakov, Appl. Catal., A. 2009, 362, 20-25.

[11] B. M. Reddy, P. M. Sreekanth, Y. Yamada, X. Xu, T. Kobayashi, Appl. Catal., A. 2002, 228, 269278.

[12] a) D. Roth, P. Gelin, M. Primet, E. Tena, Appl. Catal., A. 2000, 203, 37-45; b) D. O. Simone, T. Kennelly, n. I. brungard, R. J. Farrauto, Appl. Catal. 1991, 70, 87-100. 


\section{Table of Contents text}

Herein a robust and active combustion catalyst was prepared with three-quarter (75 wt.\%) of its composition derived from the aluminium foil waste. Microscopic techniques revealed that catalyst structure is dominated by alumina, with $\mathrm{Ti}$ found around the edges. These results open doors for the preparation of highly active and wellstructured nano-mesoporous alumina catalyst/support from aluminium foil waste and its application in acid catalysed reactions and especially in combustion reactions.

TOC:

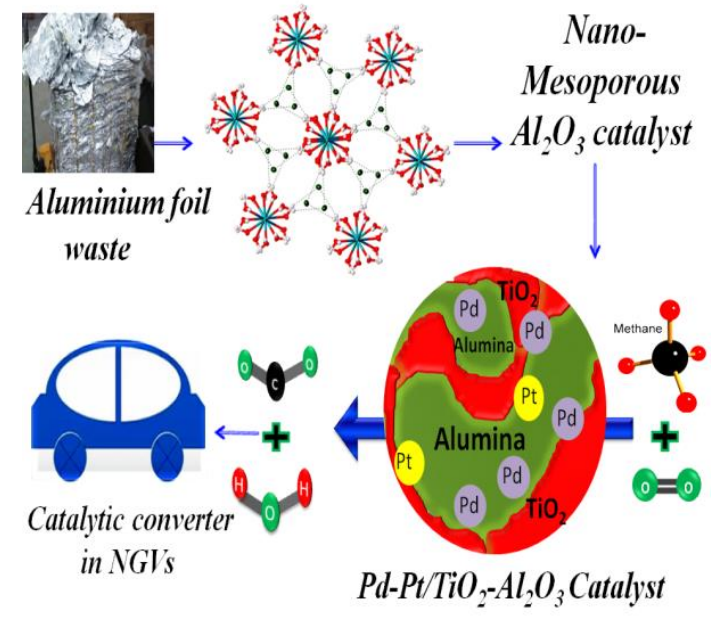

